\title{
Latent transforming growth factor binding protein 4 (LTBP4) is downregulated in mouse and human DCIS and mammary carcinomas
}

\author{
Celine Kretschmer • Anne Conradi • \\ Wolfgang Kemmner • Anja Sterner-Kock
}

Accepted: 13 March 2011 /Published online: 6 April 2011

(C) The Author(s) 2011. This article is published with open access at Springerlink.com

\begin{abstract}
Background Transforming growth factor beta (TGF- $\beta$ ) is able to inhibit the proliferation of epithelial cells and is involved in the carcinogenesis of mammary tumors. Three latent transforming growth factor- $\beta$ binding proteins (LTBPs) are known to modulate TGF- $\beta$ functions.

Methods The current study analyses the expression profiles of LTBP4, its isoforms LTBP1 and LTBP3, and TGF- $\beta 1$, TGF- $\beta 2$, TGF- $\beta 3$, and SMAD2, SMAD3 and SMAD4 in human and murine (WAP-TNP8) DCIS compared to invasive mammary tumors. Additionally mammary malignant (MCF7, Hs578T, MDA-MB361) and non malignant cell lines (Hs578BsT) were analysed. Microarray, q-PCR, immunoblot, immunohistochemistry and immunofluorescence were used.
\end{abstract}

Electronic supplementary material The online version of this article (doi:10.1007/s13402-011-0023-y) contains supplementary material, which is available to authorized users.

\section{Kretschmer}

Charité Berlin, CVK, Med. Klinik Hepatologie

\& Gastroenterologie,

Augustenburger Platz 1,

13353 Berlin, Germany

A. Conradi $\cdot$ A. Sterner-Kock $(\bowtie)$

Center for Experimental Medicine, Medical School,

University of Cologne,

Robert Kochstr. 10,

50931 Cologne, Germany

e-mail: anja.sterner-kock@uk-koeln.de

\section{W. Kemmner}

Research Group Surgical Oncology, ECRC,

Robert-Rössle-Str. 10,

13125 Berlin, Germany
Results In comparison to non-malignant tissues $(n=5)$, LTBP4 was downregulated in all human and mouse DCIS $(n=9)$ and invasive mammary adenocarcinomas $(n=5)$ that were investigated. We also found decreased expression of bone morphogenic protein 4 (BMP4) and increased expression of its inhibitor gremlin (GREM1). Treatment of the mammary tumor cell line (Hs578T) with recombinant TGF- $\beta 1$ rescued BMP4 and GREM1 expression.

Conclusion We conclude that the lack of LTBP4-mediated targeting in malignant mammary tumor tissues may lead to a possible modification of TGF- $\beta 1$ and BMP bioavailability and function.

Keywords LTBP4 - TGF- $\beta$ - DCIS · Mammary carcinoma Carcinogenesis $\cdot$ Tumour suppressor gene

\section{Introduction}

The rising use of screening mammography starting in the early 1980s resulted in an increase in detection of the ductal carcinoma in situ (DCIS) and invasive ductular carcinomas (IDCs) especially among women over 50 years of age [29]. DCIS represents $20-45 \%$ of all new cases of mammographically detected breast cancer, and about $10 \%$ of all breast carcinomas [46]. Improving diagnosis and treatments for patients will likely depend on finding unique molecular markers or other features that distinguish different types and stages of tumors from each other and from nonmalignant tissue.

Modern microarray technologies for gene expression profiling can provide such insights into the molecular features of DCIS and IDCs. Relatively few such studies of these tissues have been carried out to date and most focus on the identification of genes associated with tumor 
progression, by comparing in situ and invasive neoplasias $[33,41,48]$. One bottleneck has been the limited number of samples of mammary neoplasms, including DCIS, that are available. To overcome this problem in our study, an additional transgenic mouse model for DCIS was used [49]. The mice are transgenic for the WAP-SV40 early genome region, so the expression of the SV40 oncogene is activated by lactation. The use of these transgenic animals offers the possibility of identifying tumor-initiating factors and investigating gene expression profiles at different stages of tumor development.

Transforming growth factor- $ß \mathrm{~s}$ (TGF- $ß \mathrm{~s}$ ) have a wide range of functions and have been implicated in many types of cancer [24]. TGF-ßs belong to a large superfamily of secreted polypeptides which modulate growth and differentiation in multiple cell types and control the homeostasis of extracellular proteolysis. They play important roles during many stages of development. The putative tumor suppressor gene TGF- $\beta 1$ is able to inhibit epithelial proliferation [17] and is involved in the carcinogenesis of human mammary tumors $[9,18-20,23$, $30,52,56]$.

During development and in multiple pathological processes, the activity of all TGF- $\beta$ superfamily members is strictly regulated through association with other molecules. After secretion, TGF-ßs initially remain biologically latent. In its mature form, the molecule forms dimers that are kept inactive by an amino-terminal propeptide (LAP). Although this peptide is cleaved during the secretion of TGF- $\beta$, it remains associated with the molecule by non-covalent interactions. The activation of TGF- $\beta$ requires its dissociation from LAP [54].

In most cell types TGF- $\beta$ is secreted in a latent form associated with latent TGF- $\beta$ binding protein (LTBP) [37]. In combination, the molecules may be targeted to specific extracellular structures, providing the main means by which the spatial and temporal activity of TGF- $\beta$ is controlled. TGF- $\beta$ accumulates in the microfibrillar ECM structures in its latent form. TGF- $\beta$ extracellular matrix secretion, deposition and latency are strictly linked to their binding proteins (LTBPs).

Currently four different LTBPs have been cloned from mammals (LTBP1 to LTBP 4). LTBP1, LTBP 3 and LTBP4 bind covalently to TGF-B1-LAP [13, 39, 53, 57, 61]. LTBPs are released from the extracellular matrix (ECM) by various proteinases including plasmin [16].

There is evidence that changes in TGF- $\beta$ expression levels, signaling, and possibly other aspects of its behavior are linked to the activation of the BMP pathway. Aberrant expression patterns of BMP, which have been correlated to outcomes and prognosis in breast cancer, as well as stages of tumor progression [60], might be correlated to changes in TGF- $\beta$ signaling. Since TGF- $\beta$ function is determined by its association with LTBPs, it is not surprising to find changes in LTBP4 expression in the malignant transformation of the investigated tumors. This, in turn, might provide a link between BMP and changes in LTBP4 expression levels $[27,35]$.

LTBPs are needed for the secretion and folding of TGF- $\beta$ $[8,21,37]$; they have also been proposed to play an important role in the pathogenesis of mammary neoplasms. Some epithelial carcinomas showed lower LTBP1 and LTBP3 expression compared to non-malignant tissue taken from the same individual $[7,28,42]$. LTBP1 is downregulated in a variety of human epithelial neoplasms of the liver [45], ovaries [15] and in neuroendocrine tumors of the digestive system [6]. Dysregulated expression of LTBP isoforms seem to be related to the onset of epithelial neoplasms.

Here we investigated the possibility that changes in LTBP4 expression might be linked to the carcinogenesis of human mammary carcinomas, DCIS as well as mouse mammary tumors and DCIS. We discovered that LTBP4 is consistently downregulated in human and mouse DCIS and mammary tumors compared to primary (non-transformed) mammary epithelial cells. This suggests that the gene may be involved in neoplastic transformation of human mammary tumors and could play a role as a putative tumor suppressor gene.

\section{Material and methods}

\subsection{Mice}

WAP-TNP8 animals, which selectively synthesize the T/tantigen under the control of the WAP (whey acidic protein) promoter in the mammary gland epithelial cells, were used for this study [49]. The WAP promoter is hormonally and developmentally regulated by lactotrophic hormones. Thus expression of the SV40 large tumor antigen can be induced by mating and is directed to epithelial cells of the differentiating and lactating glands ([49]). Females were allowed to nurse their offspring for 3 to 4 weeks. Wild type mice (non-transgenic) and transgenic mice before lactation were used as negative controls and were combined as nonmalignant control samples. Mice were analysed 2 months after lactation (abbreviated as $2 \mathrm{M}$ ), 3 months after lactation $(3 \mathrm{M}), 4$ months after lactation $(4 \mathrm{M})$ and 5 months after lactation $(5 \mathrm{M})$. In this way we were able to study the different time points of the development of DCIS. Also a group of invasive ductal carcinomas (IDC) was investigated in the similar way and served as positive control. For subsequent analysis, mice were sacrificed and mammary 
glands were dissected. Tissue samples of mouse mammary glands were cut in unbiased, random, isometric planes of sections (according to Cavalieri princile) and histopathologically evaluated. The investigated WAP-TNP8 mice mainly developed DCIS 5 to 6 months after lactation. But already 2 to 3 months after lactation around $30 \%$ of the mice showed DCIS. After morphological evaluation and diagnosis predominantly high grade DCIS were identified. Tissue sections for RNA isolation were snap-frozen in liquid nitrogen and stored at $-80^{\circ} \mathrm{C}$.

For the Affymetrix gene expression analysis five samples per group (in total 40 Microarrays) were analyzed. For the subsequent quantitative real time PCR the groups were enlarged at seven mice per group.

\subsection{Human tissue}

Nineteen fresh-frozen human breast samples (non-malignant, DCIS and IDC) were obtained from the Robert-RössleBiobank at the ECRC (Experimental and Clinical Research Center). Tissue samples were cryopreserved immediately after surgery in liquid nitrogen and stored at $-80^{\circ} \mathrm{C}$. All participants gave written, informed consent. The patient cohort consisted of nine DCIS, five invasive ductal carcinoma (IDC) and five non-malignant control samples obtained from patients with breast reduction surgery. All samples were reviewed for histological classification according to nuclear grade. The human samples were tumor grade 2 and 3 (6 DCIS \& 3 IDC grade 3, 3 DCIS \& 2 IDC grade 2). Average age of the human patients was 63 years. They were all free of distant metastasis. For the human gene expression analysis (Microarray and TaqMan) the patient cohort consisted of nine DCIS, five invasive ductal carcinoma (IDC) and five healthy control samples. A second panel consisting of human formalin-fixed paraffin-embedded (FFPE) tissue samples was used for immunohistochemical staining.

\subsection{Cell culture}

Human breast cancer MCF-7 and MDA-MB-361 (ATCC, USA) cells were cultured in DMEM (ATCC, USA) supplemented with $10 \%$ fetal calf serum (Invitrogen, Karlsruhe Germany), 1\% sodiumpyruvate 100 mM (Invitrogen, Karlsruhe Germany), 1\% Glutamin $200 \mathrm{mM}$ (Invitrogen, Karlsruhe Germany), 1\% $10.000 \mathrm{U} / \mathrm{ml}$ penicillin/ $10.000 \mu \mathrm{g} / \mathrm{ml}$ streptomycin (Invitrogen, Karlsruhe Germany) at $37^{\circ} \mathrm{C}$ and $5 \% \mathrm{CO}_{2}$ in flasks.

Hs578T tumor cells (ATCC, USA) were cultured in DMEM (ATCC, USA) supplemented with $10 \%$ fetal calf serum, $2 \% 10.000 \mathrm{U} / \mathrm{ml}$ penicillin $/ 10.000 \mu \mathrm{g} / \mathrm{ml}$ streptomycin, $0,2 \mathrm{ml} / 500 \mathrm{ml}$ bovine Insulin (Roche, Mannheim
Germany) at the same conditions. The matched non tumor cell line Hs578Bst (ATCC, USA) was maintained in Hybri-care Culture-Medium (ATCC, USA) supplemented with $10 \%$ fetal calf serum, $2 \% 10.000 \mathrm{U} / \mathrm{ml}$ penicillin/ $10.000 \mu \mathrm{g} / \mathrm{ml}$ streptomycin and $30 \mathrm{ng} / \mathrm{ml}$ Epidermal Growth Factor (Invitrogen, Karlsruhe Germany) at $37^{\circ} \mathrm{C}$ and $5 \% \mathrm{CO}_{2}$. Upon reaching approximately $85 \%$ confluence, cells were detached with $0,05 \%$ trypsin and $0,02 \%$ EDTA in PBS, sub cultured in new flasks and used for the assays.

It has been shown in the literature that the chosen cell lines MCF-7, Hs578T and Hs578BsT are sensitive to TGF- $\beta$ signaling and are therefore widely used to investigate the TGF-B/BMP pathway [12, 31, 34, 55].

Conditioned medium was prepared by a 3 to $24 \mathrm{~h}$ incubation of the Hs578T or Hs578BsT cells. The medium of the receiving cell population was removed, cells were washed and then incubated with conditioned media or medium containing recombinant TGF- $\beta$ in concentrations of $(0.2$ to $>30 \mathrm{pM})$ to $1,6 \times 10^{5}$ cells.

For rescue experiments Hs578T cells were used. Recombinant TGF- $\beta 1(0.2$ to $>30 \mathrm{pM})$ was added to cells and incubated for $24 \mathrm{~h}$. BMP4 and gremlin expression was monitored by immunoblot.

\subsection{RNA isolation and RT-PCR}

Murine total cellular RNA and total cellular RNA of cell culture cells was isolated using the RNeasy Mini Kit (Qiagen, Hilden Germany) with on column DNAse I (Qiagen, Hilden Germany) digestion according to manufactures instructions including a DNAse digestion step. Human total RNA was isolated with RNeasy Lipid Tissue Mini Kit (Qiagen). On the one hand, RNA concentrations and purities were determined spectrophotometrically using a Bio Photometer (Eppendorf, Hamburg Germany) or NanoDrop $^{\circledR}$ ND-1000 (Thermo Scientific, Dreieich). $A_{260} / A_{280}$ ratios were calculated for evaluation of protein impurities. The $\mathrm{A}_{260} / \mathrm{A}_{280}$ ratio was $1.8-2.2$, suggesting that the isolated RNA was free of protein. On the other hand, RNA concentrations and purities were determined using Agilent 2100 Bioanalyzer (Agilent Technologies, Böblingen, Germany). RIN (RNA integrity number) of the used RNA samples was always about 6,7. RNA yield was between $130,3 \mathrm{ng} / \mu \mathrm{l}$ and $189,0 \mathrm{ng} / \mu \mathrm{l}$ for the human samples and $2,5 \mathrm{ng} / \mu \mathrm{l}$ and $31,7 \mathrm{ng} / \mu \mathrm{l}$ for the murine samples.

Quantitative PCR was performed using TaqMan ${ }^{\circledR}$ Gene Expression Assays and the ABI Prism ${ }^{\mathrm{TM}} 7900$ HT Sequence Detection System (Applied Biosystems, Foster City, CA, USA). Gene Expression Assay IDs are listed in Table 1. For the mice samples RNA UltraSense ${ }^{\mathrm{TM}}$ One-Step 
Table 1 Assays on demand (Applied Biosystems) and PCR Primer sequences used for the RT-PCR

\begin{tabular}{lll}
\hline & Gene & Assay-on-Demand ID/Sequence \\
\hline Murine RT-PCR assays & LTBP4 & Mm00723639_g1 \\
Human RT-PCR assays & LTBP4 & Hs00186025_m1 \\
& LTBP4 b forward & 5'-GAC GGC TAC TCA GAT GCCTC-3' \\
& LTBP4 b reverse & 5'-GCC TCT GAG ATC ACG TGT TGG-3' \\
\hline
\end{tabular}

Quantitative RT-PCR System (Invitrogen, Karlsruhe Germany) was used. Procedure was performed in accordance to the manufacturer's guide. For human RNA, cDNA synthesis was done using $1 \mu \mathrm{g}$ total RNA, Oligo(dT) primers $(500 \mu \mathrm{g} / \mathrm{ml})$ (Biotez, Berlin, Germany) and SuperScript II (200 U/ $\mu$ l) (Invitrogen, Karlsruhe Germany) according to the protocol of Invitrogen. qPCR for the human cDNA was performed using the TaqMan ${ }^{\circledR}$ Universal PCR Master Mix (Applied Biosystems, Foster City, CA, USA). For cell culture samples only a reverse transcription PCR was performed, therefore reverse transcription (RT) was performed using RT-buffer (Roche, Mannheim Germany), Expand Reverse Transcriptase, 50U/ $\mu$ l (Roche, Mannheim Germany), dNTP-Mix, 2 mM (MBI Fermentas, St. Leon-Roth Germany), Oligo(dT) Primer (Promega, Mannheim Germany), DTT (MBI Fermentas, St. LeonRoth Germany) and RNasin RNAse Inhibitor, 40U/ $\mu$ l (Promega, Mannheim Germany). PCR primers (Table 1) were designed to amplify the cDNA. Sequence information was obtained from GenBank accession number NM_003573. PCR reaction was performed using the Taq-polymerase system (Qiagen, Hilden Germany) according to the manufactures' instructions and basic protocols. For cloning, overhanging adenosine nucleotides were added using a terminal adenosyl-transferase (A-AdditionKit, Qiagen, Hilden Germany). Generally, cDNA was stored at $-20^{\circ} \mathrm{C}$.

For relative quantification of gene expression, triplicate reactions were set up. Expression of $\beta$-actin served as reference gene because $\beta$-actin expression levels were consistent throughout all samples in the cDNA microarray data. $\mathrm{H}_{2} \mathrm{O}$ wells (NTC $=$ no-template controls) were used as a negative control. Reactions were performed in 384 well format using $10 \mu \mathrm{l}$ total volume per well and a minimum of 12 ng RNA or cDNA per well. PCR products were checked by agarose gel electrophoresis.

The relative expression of the LTBP4 in the quantitative real time PCR was calculated according to the $\Delta \mathrm{Ct}$ method [32] using an internal reference sample as calibrator.

\subsection{Affymetrix GeneChip analysis}

Two-round linear amplification, using $50 \mathrm{ng}$ total RNA, was carried out for the murine samples according to
GeneChip $^{\circledR}$ Two-Cycle Target Labelling protocol (Affymetrix). In human samples cRNA was amplified from $1 \mu \mathrm{g}$ of total RNA using GeneChip ${ }^{\circledR}$ One-Cycle Target Labelling Kit (Affymetrix). The quantity of in vitro transcription and fragmentation products was assessed using the Agilent 2100 Bioanalyzer. Labelled and fragmented cRNA was hybridized for $16 \mathrm{~h}$ at $45^{\circ} \mathrm{C}$ on Affymetrix oligonucleotide Murine Genome 4302.0 or Human Genome U133 plus 2.0 Arrays. Hybridized arrays were scanned using GeneChip Scanner 3000. Linearized raw expression values were extracted. An initial analysis of the murine and mouse microarrays was performed using the Affymetrix Microarray Suite 5.0 (MAS5) software. The percentage of present calls, background noise, the scaling factor, and the ratio of $3^{\prime}$ to $5^{\prime}$ hybridization for GAPDH and $\beta$-actin were used to assess quality of hybridization. Raw image data were converted to CEL files using the Affymetrix GeneChip Operating Software (GCOS). For adjacent analyses of microarray data, the GeneSpring GX 10.0 Software (Agilent Technologies) was used. GCRMA (GC robust multiarray average) was used to perform background correction and normalization. Focus of the analysis was set on the modified expression of LTBP4 and related genes in malignant samples compared to nonmalignant samples.

The relative expression values for each gene are shown as Box and Whisker Plots. Median of the values of each group is marked with a line within the box. The box extends from the 25 th to the 75 th percentile. The whiskers extend down to the lowest value and up to the highest. The mouse data is deposited as GEO series GSE21444, and the human as GSE21422.

\subsection{Haematoxylin-Eosin stain and immunohistochemistry}

Tissue was fixed in Zink-Formalin Fix Concentrate (Thermo Shandon, USA). Tissue sections were stained using standard histology procedure according to the method described by Romeis with Haematoxylin and Eosin [44].

For immunohistochemistry the cells were incubated with the primary antibody in Dulbecco's PBS for $1 \mathrm{~h}$ at room temperature.

Rabbit antibodies against human LTBP4 (concentration $200 \mu \mathrm{g} / \mathrm{ml}$, dilution 1:100) and p-SMAD, total SMAD2 
and SMAD3 (concentration $200 \mu \mathrm{g} / \mathrm{ml}$, dilution 1:200) were obtained from Santa Cruz Biotechnology (Heidelberg Germany). The binding of the antibodies was detected using AP-conjugated secondary antibodies in the Fuchsin Substrate-Chromogen System (DakoCytomation, Hamburg Germany). The tissue sections were finally washed in TBS, treated with anti-fading reagent Glyceringelatine (Merck, Darmstadt Germany), and examined under the microscope (Zeiss IM 35, Göttingen Germany) using a $40 \times$ objective.

\subsection{Immunoblot}

Equal numbers of cells of all three cell lines were homogenized in cell-lysis-buffer $(150 \mathrm{mM} \mathrm{NaCl}, 0,1 \%$ NP-40, 10\% Glycerol, $25 \mathrm{mM}$ Natrium-ß-Glycerophosphat in $50 \mathrm{mM}$ Tris- $\mathrm{HCl}$ at $\mathrm{pH} \mathrm{7.4).} \mathrm{After} \mathrm{centrifugation} \mathrm{and}$ adding protease inhibitors (Roche, Mannheim Germany) the supernatants were used for immunoblotting.

Equal amounts of protein $(100 \mu \mathrm{g} / \mathrm{ml})$ were determined using BCA Protein Assay Kit (Pierce, USA) and applied for immunoblot reaction.

SDS-PAGE was performed according to standard protocols using 12\% SDS gels (Bio-Rad Laboratories, München Germany). Immunoblots were performed at $500 \mathrm{~V}, 196 \mathrm{~mA}$, $45 \mathrm{~min}$, using nitrocellulose membranes (Schleicher and Schuell, Dassel Germany). Electrophoretically separated proteins were transferred to nitrocellulose membranes using semidry blotting systems (Bio-Rad Laboratories, München Germany). Immunodetection was performed using BMP4, p-SMAD, SMAD2, SMAD3 antibodies (concentration $200 \mu \mathrm{g} / \mathrm{ml}$, dilution 1:100) (Santa Cruz, Heidelberg Germany), AP-conjugated secondary antibody (concentration 0,42 g/l, dilution 1:500) (DakoCytomation, Hamburg Germany) followed by colour reaction BCIP/NBT (Zymed, Berlin Germany) or ECL Western Chemiluminescent HRP Substrate (Thermo Fisher Scientific, Pittsburgh USA). Recombinant BMP4 was used as a positive control (Fig. 4). Anti- $\beta$-actin (Sigma) was used routinely as loading control.

\section{Results}

\subsection{Expression of LTBP4}

Analysis of LTBP4 in murine and human samples showed a significant reduction of mRNA expression in DCIS and invasive breast carcinoma compared to non-malignant control samples (Fig. 1a, b). In the WAP-TNP8 mice model, expression of LTBP4 was significantly reduced 2 months after activation of the SV 40 oncogene (Fig. 1a). In human samples the expression of LTBP4 was signifi- cantly reduced in both DCIS and IDC compared to nonmalignant control samples (Table 2, Fig. 1b). The findings were validated by quantitative RT-PCR in both species (Fig. 1a, b). P-values and Fold Changes of LTBP4 in the groups that were investigated are provided in Table 2. We also investigated the expression of LTBP4 in various mammary cell lines (Fig. 1c). We could show that human malignant mammary cell lines such as MDA-MB-361, MCF7 and Hs578T revealed almost complete downregulation of LTBP4. This was in sharp contrast to the nontransformed mammary cell line Hs578BsT (matched cell line to Hs578T), which showed LTBP4 expression at levels comparable to those of non-malignant human breast tissue (Fig. 1c).

\subsection{Immunohistochemistry of LTBP4 in human non-malignant ductular epithelial cells, DCIS and IDC}

Non-malignant ductular epithelial cells revealed a clear LTBP4 signal in ductular epithelial cells (Fig. 1d). There was no signal present in DCIS (Fig. 1d2, d3) or invasive carcinomas.

\subsection{Expression of TGF- $\beta$ and LTBP isoforms}

Conceivably, the downregulation of LTBP4 might interfere with TGF- $\beta$ transcription or change the balance of its three isoforms. To exclude this, we compared the transcription of TGF- $\beta 1$, TGF- $\beta 2$ and TGF- $\beta 3$ in IDCs to non-malignant breast tissue (Fig. 2c-e) using gene arrays and found no significant differences. Another question was whether the downregulation of LTBP4 downregulation might lead to the compensatory upregulation of the LTBP isoforms LTBP1 and LTBP3. These isoforms are of interest because they are the forms that bind to TGF- $\beta 1$. Changes in their expression levels might change patterns of TGF- $\beta$ secretion, and that might influence the signaling pathways that it normally activates in cells that receive the signal. But our results indicate that expression levels of LTBP1 and LTPB3 are unaffected (Fig. 2a, b), which means that cells do not produce more of the other isoforms of LTBP to compensate for lower levels of LTBP4 in DCIS and IDCs. This suggests that the isoforms are regulated independently, suggesting that each has individual functions in epithelial cells.

\subsection{SMAD expression and p-SMAD formation}

Reduced LTBP4 expression could result in impaired TGF- $\beta$ signaling. Therefore, we examined the transcriptional expression of SMAD2, SMAD3 and SMAD4, elements of the pathway. We found that the transcriptional expression of SMAD2, SMAD3 and SMAD4 in non- 
Fig. 1 Expression analysis of LTBP4 in murine and human samples. a Expression of LTBP4 in WAP-TNP8 mice. Left diagram shows the linearized raw expression values of the Affymetrix Mouse Genome 4302.0 GeneChip $^{\circledR}$ analysis; right diagram shows relative expression values of the quantitative RT-PCR. LTBP4 is significantly downregulated in the malignant tissues. b Expression of LTBP4 in human mammary tissue. Left diagram shows the linearized raw expression values of the Affymetrix Human Genome U133 Plus 2.0 GeneChip $^{\circledR}$ analysis; right diagram shows relative expression values of the quantitative RT-PCR. LTBP4 is significantly downregulated in the malignant tissues. c RT-PCR results revealed no expression of LTBP4 in the mammary carcinoma a cell lines MDAMB-361, Hs578T and MCF7 compared to the non-malignant mammary epithelial cell line Hs578BsT. D: LTBP4 immunohistochemical staining of human tissue samples. d1 shows positive staining in non-malignant breast tissue (ductus) (arrows), d2 shows no staining in DCIS, D3 shows no staining in invasive breast carcinomas. Scale bar marks $20 \mu \mathrm{m}$
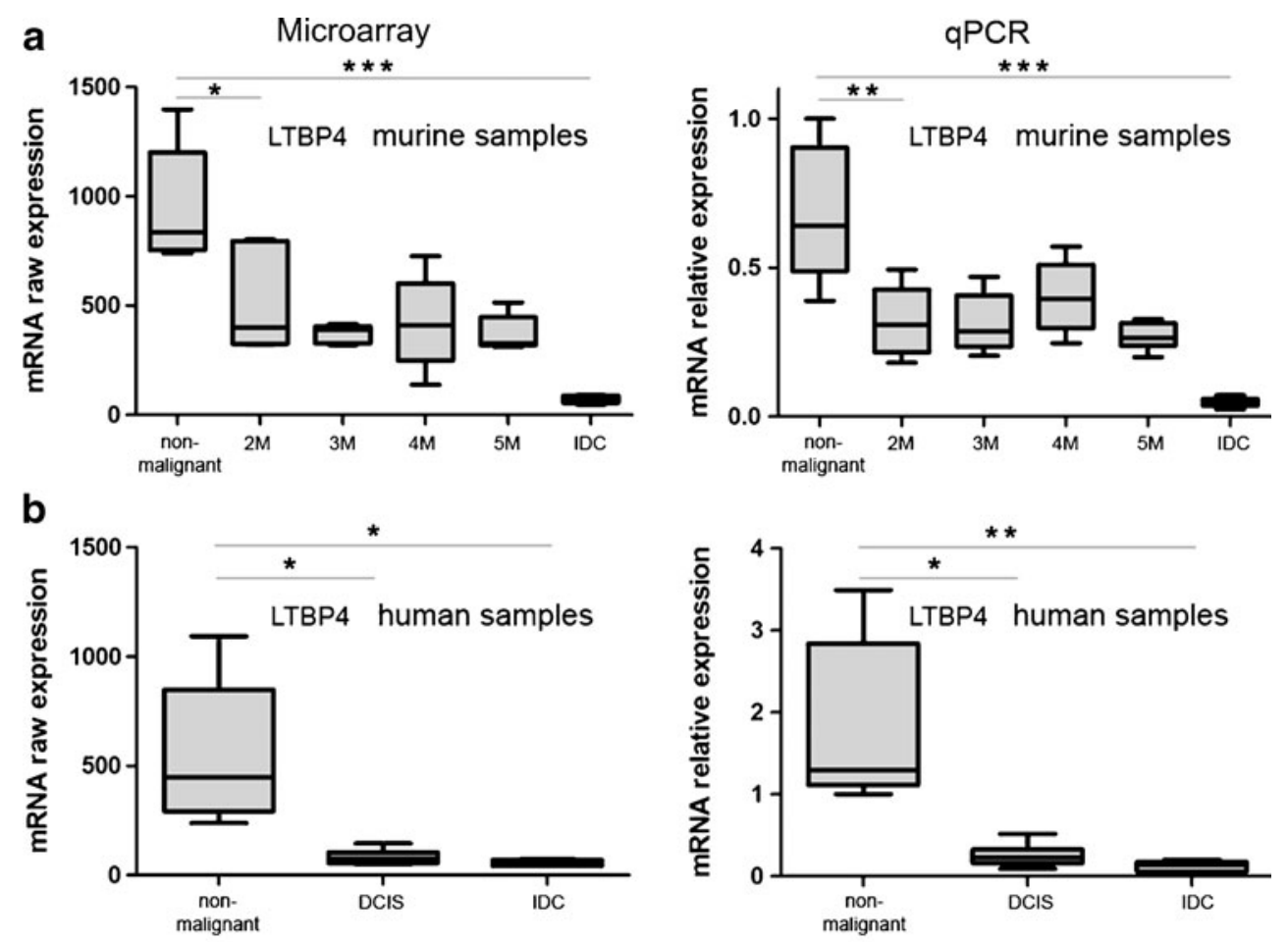

C

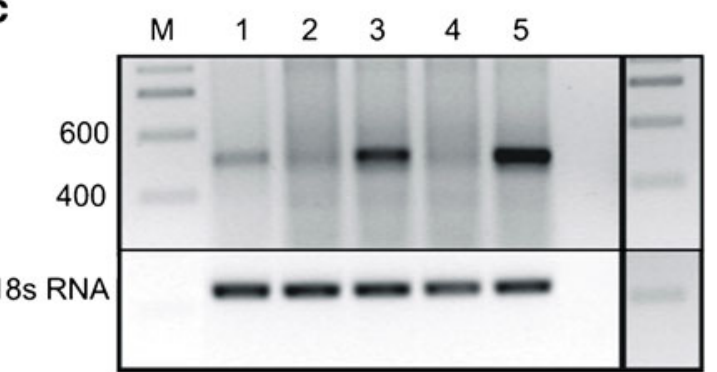
1 MDA-MB-361
2 MCF7
3 Hs578BsT
$4 \mathrm{Hs} 578 \mathrm{~T}$
5 non-malignant breast tissue

d

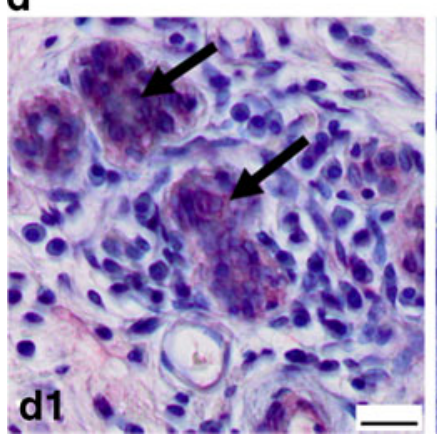

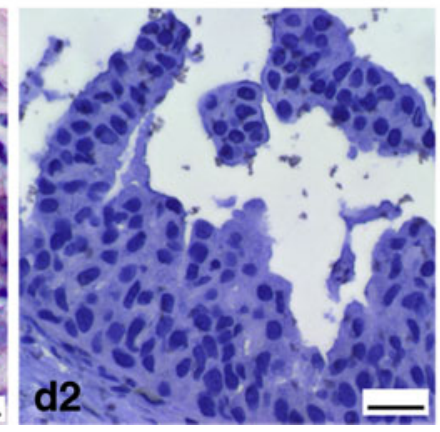

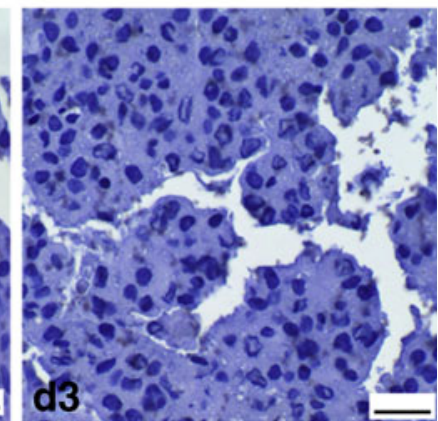

malignant mammary tissue was similar to that in DCIS and IDCs (Fig. 3a-c).

Our next step was to determine how a reduction in levels of LTBP4 expression in DCIS and IDCs affects its binding partner TGF- $\beta$. It might result in reduced secretion of TGF$\beta$, making it unavailable, or influencing its activation. To study these possible effects we established cell cultures of the mammary carcinoma cell line Hs578T and the matched non-transformed cell line Hs578BsT. The tumor cell line showed highly downregulation of LTBP4 expression compared to the non-malignant mammary cell line Hs578BsT (Fig. 1c).

TGF- $\beta$ signals are received by the TGF- $\beta$ receptor, which becomes activated and phosphorylates SMAD2 and SMAD3. They form a complex with SMAD4 that relocates into the nucleus and form a transcription complex with TGF- $\beta$ responsive genes. $p$-SMAD formation, therefore, can be used as a monitor for TGF- $\beta$ signaling within tissues 
Table 2 Down regulation of LTBP4 in malignant tissues

\begin{tabular}{|c|c|c|c|c|}
\hline & & Group & p-value & Fold change \\
\hline \multirow[t]{7}{*}{ Microarray } & \multirow{5}{*}{$\begin{array}{l}\text { Murine DCIS and IDC compared } \\
\text { to non-malignant control }\end{array}$} & $2 \mathrm{~m}$ & $1.7 \mathrm{E}-02$ & $2.1 \downarrow$ \\
\hline & & $3 \mathrm{~m}$ & 4.1E-03 & $2.1 \downarrow$ \\
\hline & & $4 \mathrm{~m}$ & $5.0 \mathrm{E}-03$ & $2.0 \downarrow$ \\
\hline & & $5 \mathrm{~m}$ & $3.5 \mathrm{E}-03$ & $2.5 \downarrow$ \\
\hline & & IDC & $9.5 \mathrm{E}-04$ & $11.7 \downarrow$ \\
\hline & \multirow{2}{*}{$\begin{array}{l}\text { Human DCIS and IDC compared } \\
\text { to non-malignant control }\end{array}$} & DCIS & $1.8 \mathrm{E}-02$ & $5.9 \downarrow$ \\
\hline & & IDC & $1.5 \mathrm{E}-02$ & $8.9 \downarrow$ \\
\hline \multirow[t]{7}{*}{ qPCR } & \multirow{5}{*}{$\begin{array}{l}\text { Murine DCIS and IDC compared } \\
\text { to non-malignant control }\end{array}$} & $2 \mathrm{~m}$ & $5.5 \mathrm{E}-03$ & $2.1 \downarrow$ \\
\hline & & $3 \mathrm{~m}$ & $4.9 \mathrm{E}-03$ & $2.2 \downarrow$ \\
\hline & & $4 \mathrm{~m}$ & $1.7 \mathrm{E}-02$ & $1.6 \downarrow$ \\
\hline & & $5 \mathrm{~m}$ & $3.5 \mathrm{E}-03$ & $2.4 \downarrow$ \\
\hline & & IDC & $5.6 \mathrm{E}-04$ & $13.4 \downarrow$ \\
\hline & \multirow{2}{*}{$\begin{array}{l}\text { Human DCIS and IDC compared } \\
\text { to non-malignant control }\end{array}$} & DCIS & $1.3 \mathrm{E}-02$ & $5.7 \downarrow$ \\
\hline & & IDC & $1.0 \mathrm{E}-02$ & $9.0 \downarrow$ \\
\hline
\end{tabular}

p-values and Fold Changes of LTBP4 in murine and human DCIS and IDC. p-values and fold Changes of LTBP4 in murine and human DCIS and IDC compared to non-malignant control samples $(2 \mathrm{~m}=2$ month after lactation, $3 \mathrm{~m}=3$ month after lactation, $4 \mathrm{~m}=4 \mathrm{month}$ after lactation, $5 \mathrm{~m}=$ 5 month after lactation, IDC=invasive ductal carcinoma). Fold Changes were calculated using the median of the non-malignant controls compared to the different time points or the invasive tumors. Malignant and premalignant tissues were down regulated compared to non-malignant controls. Microarray and quantivative real time PCR values are shown

and cells. We examined the formation of p-smad in cell culture and in mammary non-malignant tissues and mammary tumors. We found that a striking reduction in pSMAD staining in Hs578T and Hs578BsT cells (Fig. 3e1, d5) when incubated with cell conditioned media harvested after $24 \mathrm{~h}$ from Hs578T (Fig. 3d, e). Upon receptor stimulation pSMAD cytoplasmic-nuclear shuttling was induced and was mainly evident within the nucleus, dependent on kinetic considerations [47].

This indicates that the lack of LTBP4 leads to a reduction in active TGF- 31 , and therefore reduced bioavailability and pSMAD formation. In accordance with this findings, the addition of rTGF-ß1 to Hs578BsT and Hs578T results in the increased formation of p-SMAD (Fig. 3d). The p-SMAD signal could be neutralized again with the addition of neutralizing TGF- $\beta$ antibody (data not shown).

Immunohistochemical staining of $\mathrm{p}-\mathrm{SMAD} 2 / 3$ showing non-malignant breast tissue with prominent p-SMAD expression and almost complete loss of immunoreactive p-SMAD signal in mammary tumor tissue (Fig. 3f). Total SMAD2/3 in non-malignant breast tissue and in mammary tumor tissue did not show any differences in immunoreactivity. These results indicate a reduced phosphorylation of SMAD2/3 in mammary tumor tissues.

TGF- $\beta$ acts as a suppressor of cell division and a repressor of the transcription factor c-Myc [59], suggesting another potential link between TGF- $\beta$ activity and cancer. The changes of TGF- $\beta$ expression seen in the tumors might have their physiological effects by altering the behavior of c-Myc and its target genes. Therefore, we measured c-Myc expression in malignant mammary tissues and in non-malignant mammary tissues. c-Myc levels were enhanced in Hs578T cells and in mammary tumors compared to non-malignant mammary tissues (data not shown), another indication that TGF- $\beta 1$ signaling is reduced in Hs578T.

3.5 Expression of BMP4, Gremlin, ID1, and ID2 in IDC and DCIS

The connection between TGF- $\beta$ and BMP signaling prompted us to compare the expression of bone morphogenic protein 4 (BMP4) in DCIS and IDCs and non-malignant mammary tissue. The microarray analysis revealed that BMP4 expression was lower in DCIS and IDCs than in non-malignant human and murine mammary tissue (Fig. 4a, Table 3). In parallel an increase in the expression of the BMP4 inhibitor gremlin was observed (Fig. 5c, Table 4). There was also a significant decrease in expression levels of the BMP4 target gene ID1 (Fig. 5a).

\subsection{Modulation of the BMP pathway}

For in vitro analysis the human mammary carcinoma cell line Hs578T and the matched non-malignant cell line 
Fig. 2 Expression values of LTBP1 (a), LTBP3 (b), TGFB1 (c), TGFB2 (d) \& TGFB3 (e) in murine and human samples. Left panel shows the expression in WAP-TNP8 mice. The right panel shows the expression in human mammary tissue. Diagrams show the linearized raw expression values of the Affymetrix Mouse Genome 430 2.0 GeneChip $^{\circledR} /$ Affymetrix Human Genome U133 Plus 2.0 GeneChip ${ }^{\circledR}$ as Box and Whisker Plots. No significant changes in the expression profile were identified
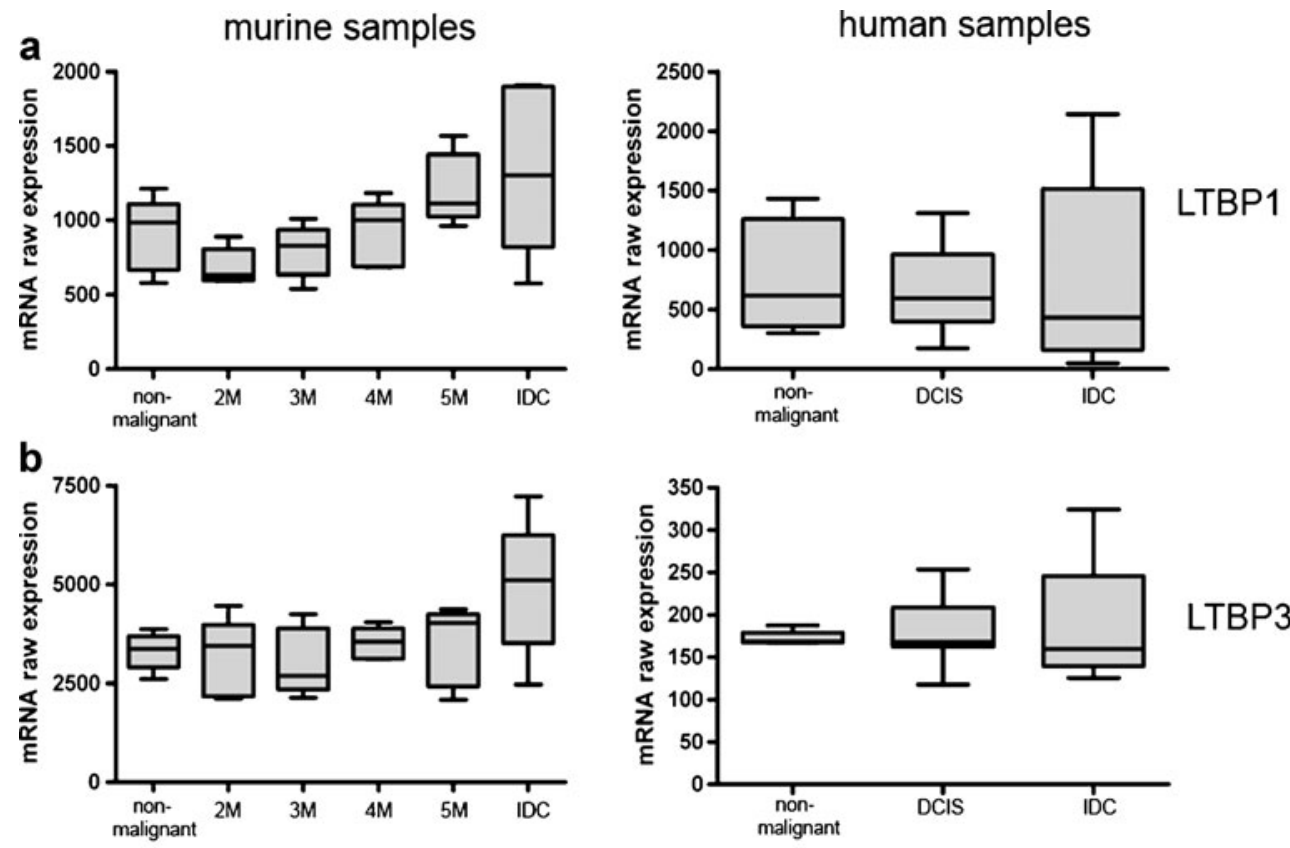

LTBP3

C
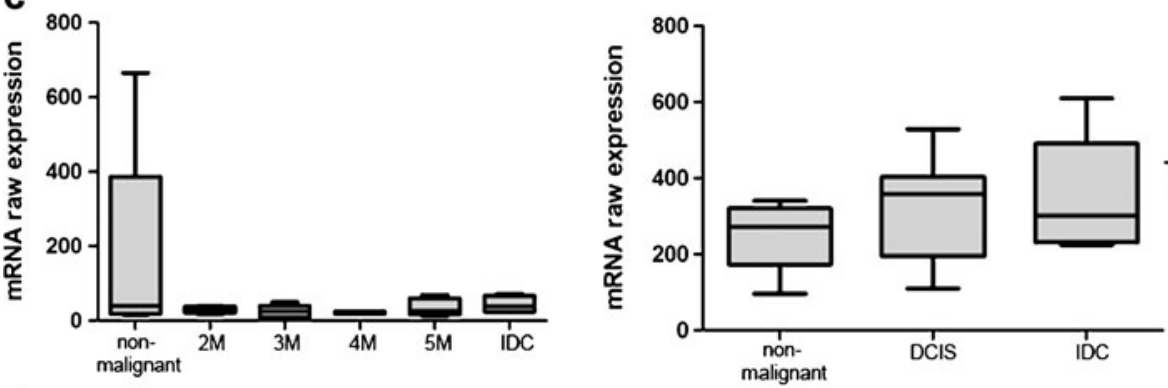

TGFB1

d
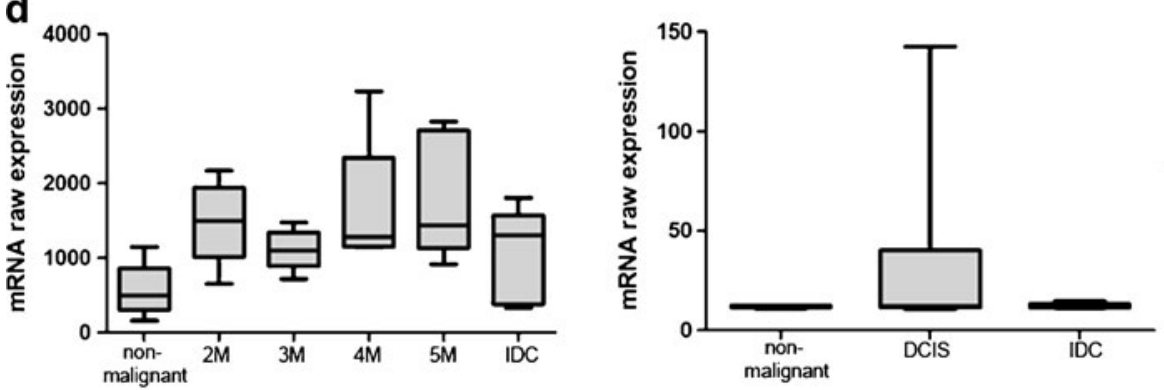

TGFB2

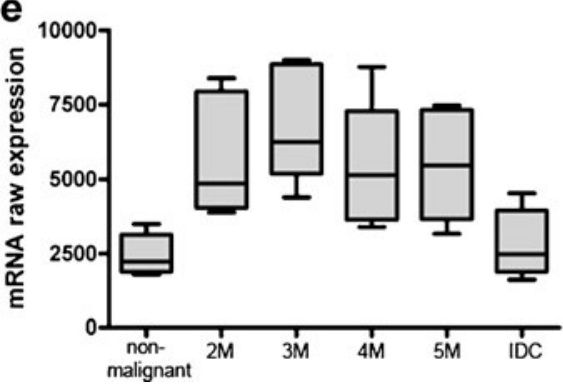

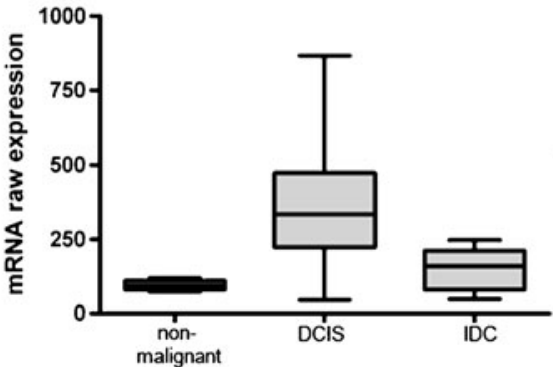

TGFB3
Hs578BsT were used. The carcinoma cell line showed clearly reduced protein levels of BMP4 (Fig. 4b). Addition of recombinant BMP4 to Hs578T cell lines rescued the BMP inhibitor gremlin and ID1 expression levels, making them comparable to levels in the untransformed cell line Hs578BsT (data not shown). 


\subsection{Rescue of BMP4 and Gremlin signaling}

To evaluate the relationship between these changes we analysed whether restoring TGF- $\beta 1$ activity and signaling in Hs578T cells would restore BMP4 and gremlin to the levels of expression seen in non-malignant mammary tissue (Fig. 4c).

To restore BMP4 activity in Hs578T, which does not express LTBP4, we cultured Hs578T cells in the presence of low-concentration TGF- $\beta 1(0,5 \mathrm{ng} / \mathrm{ml})$ in normal serum containing medium. The expression levels of BMP4 and gremlin resembled those of non-malignant mammary tissue (Fig. 4c).

Our in vivo findings show a correlation between TGF- $\beta$ bioavailability and reduced expression of BMP4. Furthermore, the results indicate that BMP4 signaling is significantly modified in mammary neoplasms, resulting in the dysregulation of the BMP4 target genes Gremlin1 and ID1 and ID2.

\section{Discussion}

The present study investigated the possible role of TGF- $\beta$ binding protein 4 (LTBP4) and TGF- $\beta$ in human DCIS and mammary tumors and in mouse mammary carcinomas and DCIS. To date, little is known about the interdependency of human DCIS and invasive mammary carcinomas and the expression of TGF- $\beta$ and its binding protein LTBP4.

What has been established so far is that all of the four TGF- $\beta$ binding proteins identified to date (LTBP1 to LTBP4) play an essential role in the secretion and activation of TGF- $\beta[36,54]$. It has also been shown that LTBP4 knock out mice developed epithelial carcinomas, indicating that LTBP4 is involved in the pathogenesis of epithelial tumors [51]. The current study investigated the expression profiles of LTBP4 and TGF- $\beta 1$ in human and mouse invasive mammary tumors and DCIS in a quantitative manner. Furthermore downstream effects of TGF- $\beta$ signaling were monitored.

Here we have demonstrated that LTBP4 is downregulated in human and murine mammary tumors (which were classified as adenocarcinomas according to WHO) and DCIS in comparison to control tissue of an identical genetic background. This downregulation is clearly associated with tumor cells; our experiments suggest that it is functionally important and provide a potential model for understanding its effects on signaling pathways, particular target genes, and tumorogenesis.

Once the process of cancer is underway, however, other mechanisms appear to step in to guide a tumor's development. We did not find further changes in LTBP4 expression that could be linked to the specific tumor type, its growth, or its metastatic potential.
These findings are supported by Mauel et al., who demonstrated a marked decrease in LTBP4 mRNA expression in the two mammary carcinoma cell lines (MCF-7 and Hs578T) compared to the non-malignant matched control cell line Hs578BsT [34].

Molecules such as LTBP4 help regulate aspects of the TGF- $\beta$ signaling pathway by binding to TGF- $\beta 1$-LAP and influencing its localization and activation. To document a possible correlation between LTBP4 and TGF- $\beta 1$, we analysed the expression of TGF- $\beta 1$. In DCIS and invasive carcinomas (human and mouse) the results showed no change in the expression of TGF- $\beta 1$. Also Mauel et al. analysed TGF- $\beta 1$ and TGF- $\beta 2$ expression in human mammary carcinoma cell lines (MCF-7, Hs578T) compared to matched control cells (Hs578BsT). They found no upregulation of TGF- $\beta 1$ or TGF- $\beta 2$ in the human mammary carcinoma cell lines [34].

Others have proposed that an increased expression of TGF- 32 could be a possible compensatory mechanism in response to the lack of TGF- $\beta 1$ [27]. Koli et al. describe that the downregulation of LTBP4 in the lung tissue of mice leads to a reduction of the activity of TGF- $\beta 1$ and no increase in the expression of TGF- $\beta 2$ and TGF- $\beta 3$, which agrees with the present results $[25,26]$.

Bascom and colleagues $[1,2]$ stated that TGF- $\beta 1$ is a potent repressor of TGF- $\beta 2$ and TGF- $\beta 3$. The regulatory mechanisms that are responsible for the expression of TGF- $\beta 1$, TGF- $\beta 2$ and TGF- $\beta 3$ and their crosstalk are mostly unknown [1]. It is also not known whether this phenomenon is cell-type specific. However, it is known that the reduced expression of TGF- $\beta 1$ would have a proproliferative effect on epithelial cells, which could be a potential inducer of a pro-carcinogenic process in epithelial cells.

It is not clear whether LTBP4 downregulation results in transformation of epithelial cells and potential neoplasia, or if this downregulation follows upon the cells' transformation. Koli et al. described a markedly reduced transcription rate for LTBP1, LTBP2, LTBP3 and LTBP4 transcription rate in SV40-transformed human embryonic lung fibroblasts $[25,26]$. Therefore, it seems that malignant transformation of an epithelial cell type results in reduced LTBP expression that is not necessarily LTBP-isoform specific [26]. The fact that the transformed cell lines BA 13 and AT 1080 exhibited reduced LTBP4 expression compared to the non-transformed cell line WI 38 provides further support for the idea that malignant transformation is correlated to reduced LTBP expression [28, 54]. This observation was supported by Henriksen and colleagues, who found reduced LTBP1 expression in human ovarian carcinomas compared to non-malignant matched control tissue [15]. Furthermore, the expression of TGF- $\beta$ binding proteins LTBP1 and LTBP3 is decreased in epithelial tumors [7, 28, 42]. The 


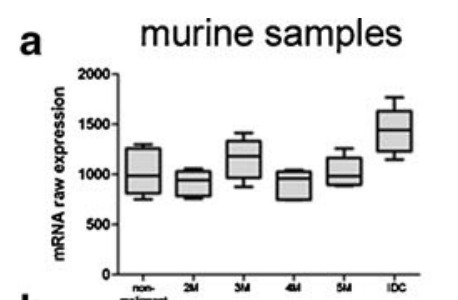

b
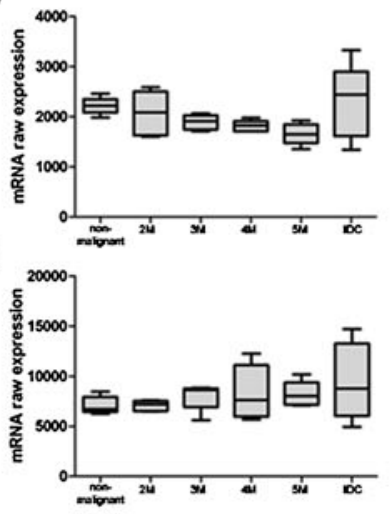

Hs578BsT

+ cond. media of Hs578T

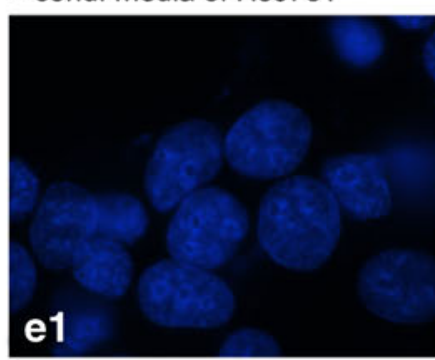

human samples
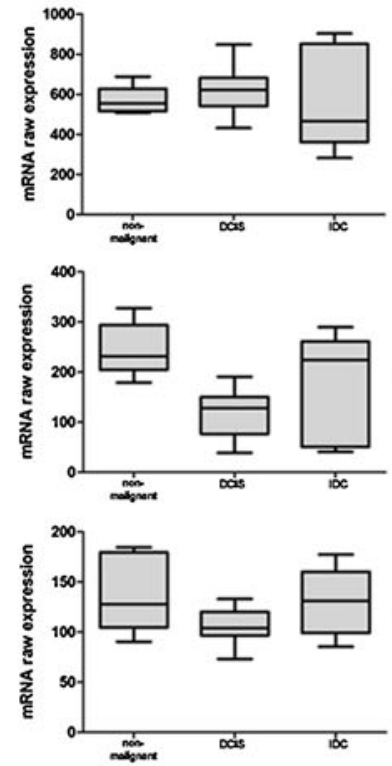

Hs578 BsT

+ cond. media of Hs578BsT

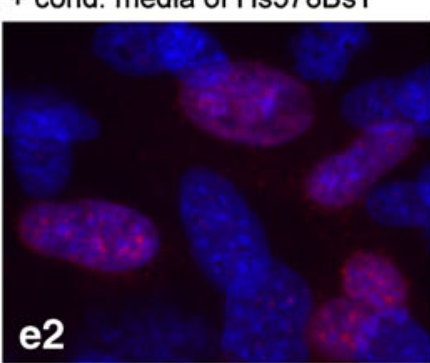

d

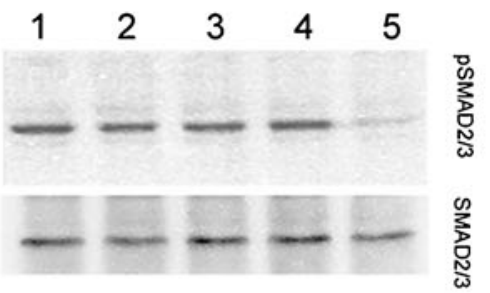

supernatant of $>$ to

$1 \mathrm{Hs} 578 \mathrm{BsT}>\mathrm{Hs} 578 \mathrm{BsT}$

2 Hs578BsT > Hs578T

3 TGFB $>$ Hs578BsT

4 TGFB > Hs578T

$5 \mathrm{Hs} 578 \mathrm{~T}>\mathrm{Hs} 578 \mathrm{BsT}$
Hs578T

+ cond media of Hs578BsT

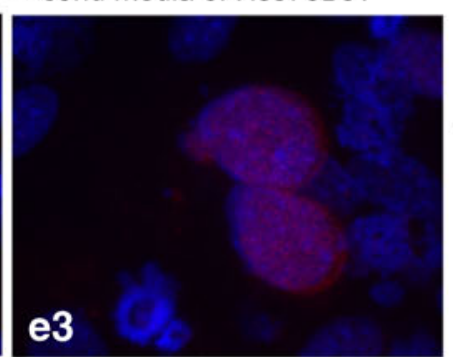

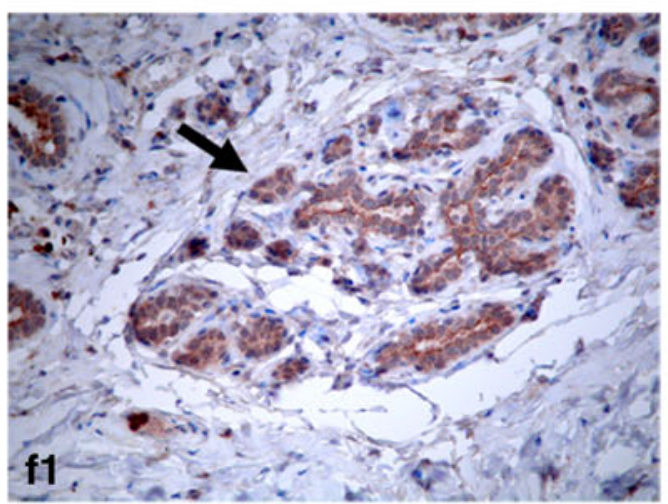

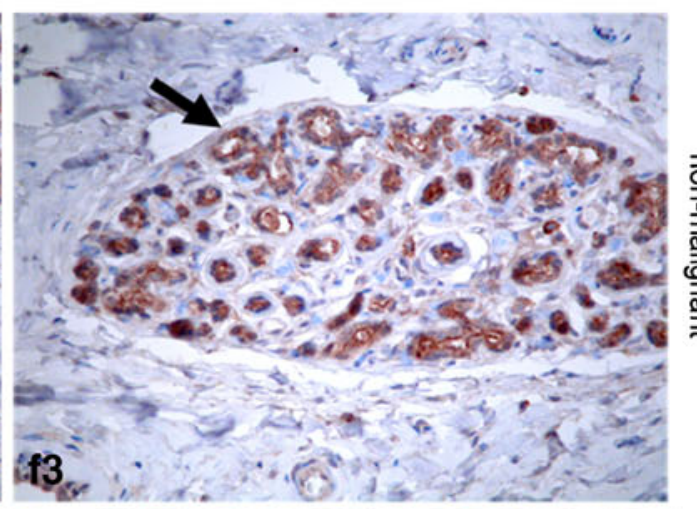

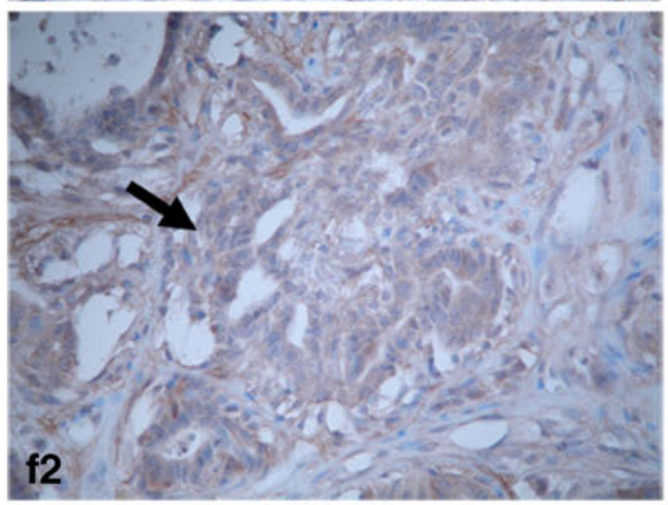

pSMAD $2 / 3$

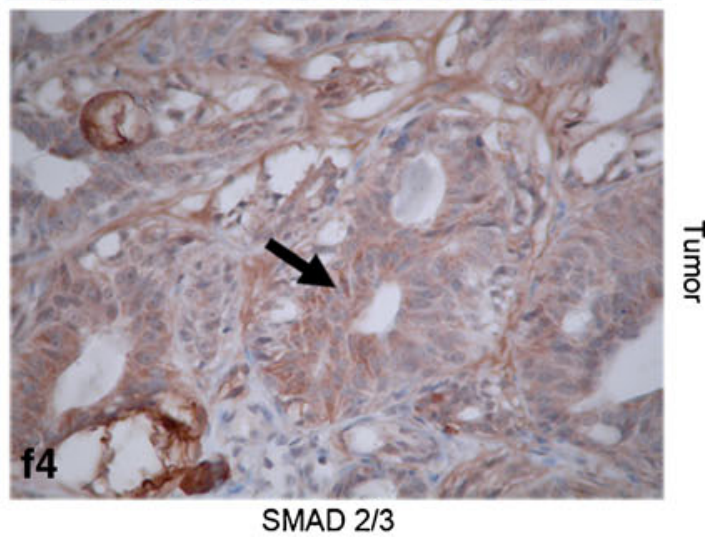


Fig. 3 RNA expression values of SMAD2 (a), SMAD3 (b) and SMAD4 (c) in murine and human samples. Left panel: Expression in WAP-TNP8 mice. Right panel: Expression in human mammary tissue. Diagrams show the linearized raw expression values of the Affymetrix Mouse Genome 4302.0 GeneChip ${ }^{\circledR} /$ Affymetrix Human Genome U133 Plus 2.0 GeneChip ${ }^{\circledR}$. No changes in mRNA expression were identified for SMAD2, SMAD3 and SMAD4. D: Immunoblot analysis of p-SMAD expression after transfer of conditioned medium to Hs578BsT or Hs578T cells or addition of recombinant TGF-ß31 (d1-5). e Immunfluorescence of p-SMAD after incubation of Hs578BsT with conditioned media of Hs578T (e1), incubation of Hs578BsT cells with supernatant of Hs578BsT cells (e2), after incubation of Hs578T cells with supernatant of Hs578BsT cells (e3). Red immunoreactivity shows p-SMAD2/3 expression, blue staining is DAPI nucleic acid staining. $\mathbf{f}$ Immunohistochemical staining of $\mathrm{p}$-SMAD2/3 showing non-malignant unchanged breast tissue with prominent p-SMAD expression (arrow) (f1) and almost complete loss of immunoreactive p-SMAD signal in mammary tumor tissue (F2) and total SMAD2/3 in non-malignant breast tissue (arrow) (f3) and prominent total SMAD2/3 staining in mammary tumor tissue

downregulation of LTBP isoforms seems to be associated with the formation of epithelial neoplasms.

It has been postulated that reduced LTBP expression in malignant tumors leads to a diminished secretion of TGFB1, which results in reduced bioavailability of extracellular TGF- $\beta 1$. This leads to a lack of its tumor suppressive effects in epithelial cells [8, 38].

LTBPs play a fundamental role as cellular chaperons for latent TGF- $\beta$ [50]. It seems that the LTBPs have an indirect tumor suppressive effect by supporting extracellular transport of TGF- $\beta$. It is not yet known whether there is an LTBP receptor that would allow LTBPs to act via direct receptor ligand interaction with the target cell [21]. A downregulation of LTBP4 in neoplastic mammary epithelial cells in vitro, is possibly indirectly correlated to the lack of the tumor suppressive properties of TGF- $\beta 1$ [34]. The possible lack of extracellular TGF- $\beta 1$ might play a role in the induction of neoplastic transformation of mammary epithelial cells.

The data indicate that reduced LTBP4 expression might possibly lead to reduced TGF- $\beta$ activity and possibly reduced downstream signaling of TGF- $\beta$.

Overall the results indicate a decrease in active TGF- $\beta 1$ signaling in neoplastic mammary tissue (DCIS and IDCs). A decrease of TGF- $\beta 1$ signaling may result from decreased synthesis, processing, or secretion of TGF- 31 . Therefore we assayed conditioned media from cells which did not express LTBP4 and monitored TGF- $\beta$ signaling by evaluating SMAD-phosphorylation, an indicator of active TGF- $\beta$ signaling. We found reduced SMAD signaling and partly modified activation of downstream targets (data not shown).

This is in accordance with Yoshinaga et al., who generated mice in which TGF- $\beta$ cannot bind to LTBP [62]. These mice develop epithelial tumors which are associated with aberrant TGF- $\beta$ signaling. Epithelial tumors due to disturbed TGF- $\beta$ signaling are also observed in mouse models of smad3-/and APC delta 16, SMAD $4+/-$. In addition human colon carcinomas are often associated with mutations of components of the TGF- $\beta$ signaling pathway $[3,10,14,22,58]$.

Previously it was assumed that TGF- $\beta$ acted directly on the epithelial cells, and that the loss of TGF- $\beta$ signaling was suppressed either in stromal cells or in T-cells [3]. But the
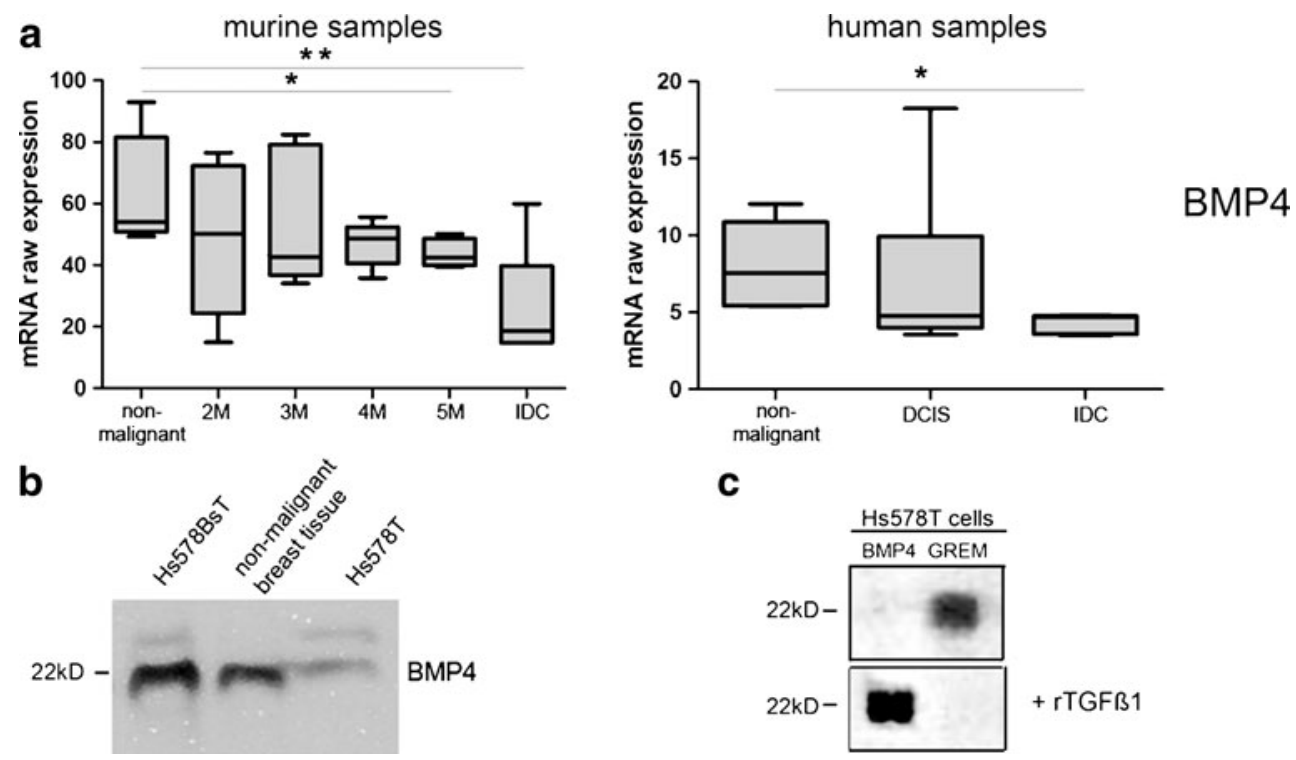

C

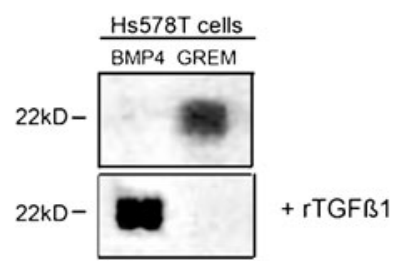

Fig. 4 Expression values of BMP4 in murine and human samples. a Expression of BMP4 in WAP-TNP8 mice (left) and in human tissue samples (right). Box and Whisker plots show the linearized raw expression values of the Affymetrix Mouse Genome 4302.0 GeneChip ${ }^{\mathbb{R}} /$ Affymetrix Human Genome U133 Plus 2.0. The expression of BMP4 is significantly reduced in the malignant tissues. $\mathbf{b}$ The

immunoblot shows a reduced expression of BMP4 in cell culture tumor cells compared to non malignant cells and non-malignant human mammary tissue. c Rescue of BMP4 expression and its inhibitor gremlin in Hs578T cells to levels of non-malignant mammary tissue by restoring TGF- $\beta 1$ activity via addition of recombinant TGF- $\beta 1$ 
Table 3 Down regulation of BMP4 in malignant tissues. p-values and Fold Changes of BMP4 in murine and human DCIS and IDC

\begin{tabular}{|c|c|c|c|}
\hline & Group & p-value & Fold change \\
\hline \multirow[t]{5}{*}{ Murine DCIS and IDC compared to non-malignant control } & $2 \mathrm{~m}$ & 1,6E-01 & $1,1 \downarrow$ \\
\hline & $3 \mathrm{~m}$ & $2,6 \mathrm{E}-01$ & $1,3 \downarrow$ \\
\hline & $4 \mathrm{~m}$ & $5,5 \mathrm{E}-02$ & $1,1 \downarrow$ \\
\hline & $5 \mathrm{~m}$ & $3,5 \mathrm{E}-02$ & $1,3 \downarrow$ \\
\hline & IDC & $6,2 \mathrm{E}-03$ & $2,9 \downarrow$ \\
\hline \multirow[t]{2}{*}{ Human DCIS and IDC compared to non-malignant control } & DCIS & $3,4 \mathrm{E}-01$ & $1,6 \downarrow$ \\
\hline & IDC & 2,0E-02 & $1,6 \downarrow$ \\
\hline
\end{tabular}

p-values and Fold Changes of BMP4 in murine and human DCIS and IDC compared to non-malignant control samples $(2 \mathrm{~m}=2 \mathrm{month}$ after lactation, $3 \mathrm{~m}=3$ month after lactation, $4 \mathrm{~m}=4$ month after lactation, $5 \mathrm{~m}=5$ month after lactation, IDC = invasive ductal carcinoma). Fold Changes were calculated using the median of the non-malignant controls compared to the different time points or the invasive tumors. Malignant and premalignant tissues were down regulated compared to non-malignant controls. Microarray values are shown

mice also develop tumors in tissues that have normal TGF$\beta$ signaling, such as the stomach or intestine. Therefore, the critical function of TGF- $\beta$ in the tumor microenvironment may be rather to control tumor growth.

We found no inhibition of TGF- $\beta$ synthesis, but benign human mammary cells contained significantly more active TGF- $\beta$ as assayed by p-SMAD formation in vivo and in vitro. Furthermore the results showed that BMP4, which belongs to the TGF- $\beta$ superfamily, has been implicated in the development and progression of malignant mammary neoplasms. BMP4 directly promotes proliferation of breast cancer cells $[17,24,30,56]$. Our results demonstrated reduced BMP4 (as well as reduced active TGF- $\beta$ ) in DCIS and IDCs which correlated with reduced active TGF- $\beta 1$.
Fig. 5 Expression values of ID1 (a), ID2 (b) and GREM1 (c) in murine and human samples. Left panel: Expression in WAP-TNP8 mice, right panel: Expression in human mammary tissue. Diagrams show the linearized raw expression values of the Affymetrix Mouse Genome 430 2.0 GeneChip $^{\circledR} /$ Affymetrix Human Genome U133 Plus 2.0 GeneChip ${ }^{\circledR}$. Expression of ID1 is decreased in malignant tissues in both murine and human samples. Expression of ID2 and GREM1 is increased in malignant tissues
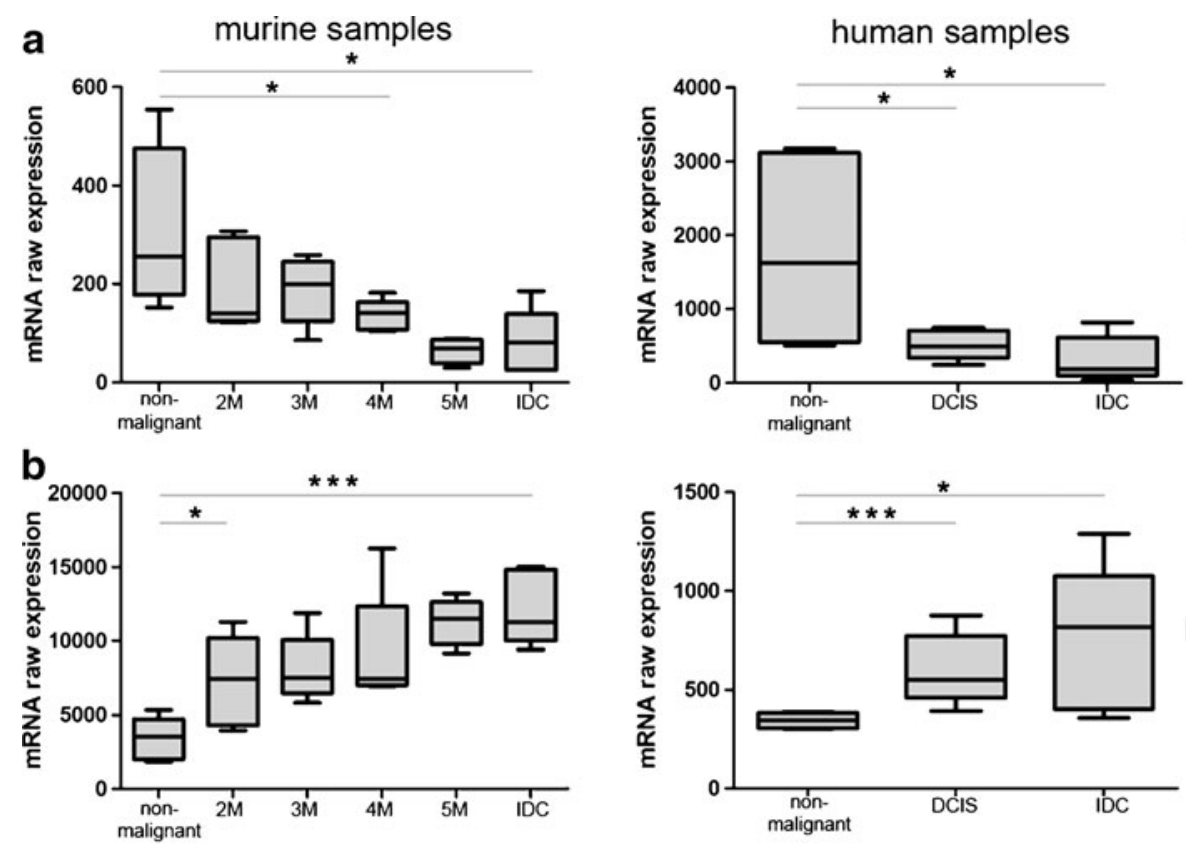

ID1
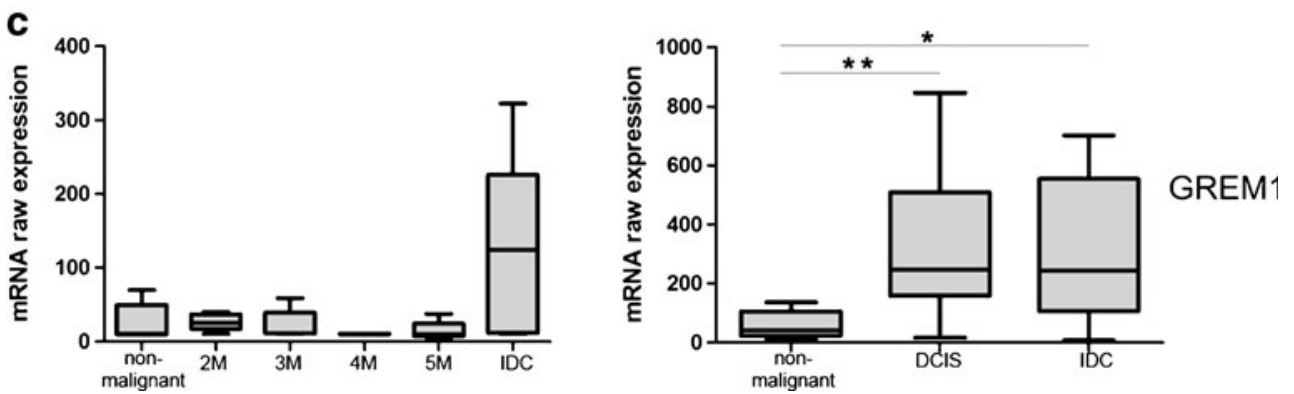
Table 4 p-values and Fold Changes of ID1, ID2 and GREM1 in murine and human DCIS and IDC

\begin{tabular}{|c|c|c|c|c|}
\hline & & Group & p-value & Fold change \\
\hline \multirow[t]{7}{*}{ ID1 } & \multirow[t]{5}{*}{ Murine DCIS and IDC compared to non-malignant control } & $2 \mathrm{~m}$ & $1,1 \mathrm{E}-01$ & $1,83 \downarrow$ \\
\hline & & $3 \mathrm{~m}$ & $8,6 \mathrm{E}-02$ & $1,28 \downarrow$ \\
\hline & & $4 \mathrm{~m}$ & $3,6 \mathrm{E}-02$ & $1,81 \downarrow$ \\
\hline & & $5 \mathrm{~m}$ & $1,3 \mathrm{E}-02$ & $3,67 \downarrow$ \\
\hline & & IDC & $1,5 \mathrm{E}-02$ & $3,14 \downarrow$ \\
\hline & \multirow[t]{2}{*}{ Human DCIS and IDC compared to non-malignant control } & DCIS & $4,5 \mathrm{E}-02$ & $3,26 \downarrow$ \\
\hline & & IDC & $3,1 \mathrm{E}-02$ & $8,66 \downarrow$ \\
\hline \multirow[t]{7}{*}{ ID2 } & \multirow[t]{5}{*}{ Murine DCIS and IDC compared to non-malignant control } & $2 \mathrm{~m}$ & $2,2 \mathrm{E}-02$ & $2,13 \uparrow$ \\
\hline & & $3 \mathrm{~m}$ & $3,1 \mathrm{E}-03$ & $2,15 \uparrow$ \\
\hline & & $4 \mathrm{~m}$ & $1,3 \mathrm{E}-02$ & $2,13 \uparrow$ \\
\hline & & $5 \mathrm{~m}$ & $1,6 \mathrm{E}-05$ & $3,27 \uparrow$ \\
\hline & & IDC & $1,9 \mathrm{E}-04$ & $3,21 \uparrow$ \\
\hline & \multirow[t]{2}{*}{ Human DCIS and IDC compared to non-malignant control } & DCIS & $6,2 \mathrm{E}-04$ & $1,60 \uparrow$ \\
\hline & & IDC & $3,4 \mathrm{E}-02$ & $2,36 \uparrow$ \\
\hline \multirow[t]{7}{*}{ GREM1 } & \multirow[t]{5}{*}{ Murine DCIS and IDC compared to non-malignant control } & $2 \mathrm{~m}$ & $1,1 \mathrm{E}-01$ & $2,39 \uparrow$ \\
\hline & & $3 \mathrm{~m}$ & $8,6 \mathrm{E}-02$ & $1,10 \uparrow$ \\
\hline & & $4 \mathrm{~m}$ & $3,6 \mathrm{E}-02$ & $0,98 \uparrow$ \\
\hline & & $5 \mathrm{~m}$ & $1,3 \mathrm{E}-02$ & $0,91 \uparrow$ \\
\hline & & IDC & $1,5 \mathrm{E}-02$ & $11,69 \uparrow$ \\
\hline & \multirow[t]{2}{*}{ Human DCIS and IDC compared to non-malignant control } & DCIS & $9,0 \mathrm{E}-03$ & $6,03 \uparrow$ \\
\hline & & IDC & 4,7E-02 & $5,95 \uparrow$ \\
\hline
\end{tabular}

p-values and Fold Changes of ID1, ID2 and GREM1 in murine and human DCIS and IDC compared to non-malignant control samples ( 2 m= 2 month after lactation, $3 \mathrm{~m}=3$ month after lactation, $4 \mathrm{~m}=4$ month after lactation, $5 \mathrm{~m}=5$ month after lactation, IDC = invasive ductal carcinoma). Fold Changes were calculated using the median of the non-malignant controls compared to the different time points or the invasive tumors. For ID1 Fold Changes represent lower expression compared to controls, for ID2 and GREM1 Fold Changes represent enhanced expression in malignant tissues compared to non-malignant controls. Microarray values are shown.

Aberrant expression of BMPs and changes in BMP4 signaling have been implicated in breast cancer. The expression profiles of some BMPs in primary mammary tumors differ significantly. Recent studies have provided evidence that activation of BMP signaling may contribute to aggressive behaviour of the cells. Gremlin, BMP4 antagonist and downstream target genes ID1 and ID2 have been shown to prevent metastasis. Our results demonstrate downregulation of BMP4 in neoplastic tissues compared to non-malignant matched controls.

Decreased expression levels of BMP4 isoforms such as BMP2, BMP4, BMP6 and BMP7 in breast carcinoma tissue compared to tumor-free resection margins are frequently found. These decreased BMP4 transcription levels are often associated with bone metastasis [5], poor clinical outcome and prognosis [4].

Although changes in the expression of specific BMPs such as BMP4 in breast cancer are still the subject of controversy, the aberrant expression of BMP4 has been indicated in the development and progression of breast cancer. The aberrations in the expression of BMP and associated targets may be due to a modified activation of TGF- $\beta$, which in turn is possibly dependent on LTBP4 expression. Accordingly, gremlin as a BMP4 antagonist was highly expressed in cancer cells [40] including breast cancer. However the role of gremlin and other BMP antagonists in breast cancer is far from clear.

Our microarray analysis revealed that BMP4 expression was reduced in cancer cells in parallel with the increase of expression of its inhibitor gremlin. Downregulation of the BMP pathway was also reflected by the down-regulation of the BMP4 target gene ID2. In addition, CTGF, which is a direct target of both BMP4 and TGF-B1 (data not shown), was highly down-regulated in different epithelial cancer cells. The addition of recombinant TGF- $\beta 1$ partially rescued the BMP4 expression phenotype, further indicating the importance of this signaling cascade for the development of the LTBP-4 -/- phenotype.

In summary these results indicate that reduced LTBP4 expression in mammary neoplasms modulates the bioavail- 
ability of TGF- $\beta$ as well as BMP4 expression with modulation of the downstream signaling cascade, leading to reduced SMAD signaling and reduced activation of target genes. The results show that this modulation of TGF$B$ dependent target genes are a consequence of reduced LTBP4 expression.

Acknowledgements The authors thank Josephine Grosch and Irmgard Henke for excellent technical assistance. Especially we thank Russ Hodge for carefully reading of the manuscript and helpful comments and Robert Stark for reading of the manuscript.

Open Access This article is distributed under the terms of the Creative Commons Attribution Noncommercial License which permits any noncommercial use, distribution, and reproduction in any medium, provided the original author(s) and source are credited.

\section{References}

1. C.C. Bascom, N.J. Sipes, R.J. Coffey, H.L. Moses, Regulation of epithelial cell proliferation by transforming growth factors. J. Cell. Biochem. 39, 25-32 (1989)

2. C.C. Bascom, J.R. Wolfshohl, R.J. Coffey Jr., L. Madisen, N.R. Webb, A.R. Purchio, R. Derynck, H.L. Moses, Complex regulation of transforming growth factor beta 1 , beta 2 , and beta 3 mRNA expression in mouse fibroblasts and keratinocytes by transforming growth factors beta 1 and beta 2. Mol. Cell. Biol. 9, 5508-5515 (1989)

3. N.A. Bhowmick, A. Chytil, D. Plieth, A.E. Gorska, N. Dumont, S. Shappell, M.K. Washington, E.G. Neilson, H.L. Moses, TGF-beta signaling in fibroblasts modulates the oncogenic potential of adjacent epithelia. Science 303, 848-851 (2004)

4. D. Bobinac, I. Maric, S. Zoricic, J. Spanjol, G. Dordevic, E. Mustac, Z. Fuckar, Expression of bone morphogenetic proteins in human metastatic prostate and breast cancer. Croat. Med. J. 46, 389-396 (2005)

5. J.T. Buijs, N.V. Henriquez, P.G. van Overveld, G. van der Horst, I. Que, R. Schwaninger, C. Rentsch, D.P. Ten, A.M. CletonJansen, K. Driouch, R. Lidereau, R. Bachelier, S. Vukicevic, P. Clezardin, S.E. Papapoulos, M.G. Cecchini, C.W. Lowik, G. van der Pluijm, Bone morphogenetic protein 7 in the development and treatment of bone metastases from breast cancer. Cancer Res. 67, 8742-8751 (2007)

6. A. Chaudhry, K. Oberg, A. Gobl, C.H. Heldin, K. Funa, Expression of transforming growth factors beta 1, beta 2, beta 3 in neuroendocrine tumors of the digestive system. Anticancer Res. 14, 2085-2091 (1994)

7. S.L. Dallas, S. Park-Snyder, K. Miyazono, D. Twardzik, G.R. Mundy, L.F. Bonewald, Characterization and autoregulation of latent transforming growth factor beta (TGF beta) complexes in osteoblastlike cell lines. Production of a latent complex lacking the latent TGF beta-binding protein. J. Biol. Chem. 269, 6815-6821 (1994)

8. S. Eklov, K. Funa, H. Nordgren, A. Olofsson, T. Kanzaki, K. Miyazono, S. Nilsson, Lack of the latent transforming growth factor beta binding protein in malignant, but not benign prostatic tissue. Cancer Res. 53, 3193-3197 (1993)

9. A.E. Elkak, R.F. Newbold, V. Thomas, K. Mokbel, Is telomerase reactivation associated with the down-regulation of TGF beta receptor-II expression in human breast cancer? Cancer Cell Int 3, 9 (2003)

10. K. Eppert, S.W. Scherer, H. Ozcelik, R. Pirone, P. Hoodless, H. Kim, L.C. Tsui, B. Bapat, S. Gallinger, I.L. Andrulis, G.H. Thomsen, J.L. Wrana, L. Attisano, MADR2 maps to 18q21 and encodes a TGFbeta- regulated MAD-related protein that is functionally mutated in colorectal carcinoma. Cell 86, 543-552 (1996)

11. K.C. Flanders, N.L. Thompson, D.S. Cissel, E. Van ObberghenSchilling, C.C. Baker, M.E. Kass, L.R. Ellingsworth, A.B. Roberts, M.B. Sporn, Transforming growth factor-beta 1: histochemical localization with antibodies to different epitopes. J. Cell Biol. 108, 653-660 (1989)

12. R.S. Frey, K.M. Mulder, TGFbeta regulation of mitogen-activated protein kinases in human breast cancer cells. Cancer Lett. 117, 41-50 (1997)

13. M.A. Gibson, G. Hatzinikolas, E.C. Davis, E. Baker, G.R. Sutherland, R.P. Mecham, Bovine latent transforming growth factor beta 1-binding protein 2: molecular cloning, identification of tissue isoforms, and immunolocalization to elastin-associated microfibrils. Mol. Cell. Biol. 15, 6932-6942 (1995)

14. W.M. Grady, L.L. Myeroff, S.E. Swinler, A. Rajput, S. Thiagalingam, J.D. Lutterbaugh, A. Neumann, M.G. Brattain, J. Chang, S.J. Kim, K. W. Kinzler, B. Vogelstein, J.K. Willson, S. Markowitz, Mutational inactivation of transforming growth factor beta receptor type II in microsatellite stable colon cancers. Cancer Res. 59, 320-324 (1999)

15. R. Henriksen, A. Gobl, E. Wilander, K. Oberg, K. Miyazono, K. Funa, Expression and prognostic significance of TGF-beta isotypes, latent TGF-beta 1 binding protein. TGF-beta type I and type II receptors, and endoglin in normal ovary and ovarian neoplasms. Lab Invest 73, 213-220 (1995)

16. M. Hyytiainen, J. Taipale, C.H. Heldin, J. Keski-Oja, Recombinant latent transforming growth factor beta-binding protein 2 assembles to fibroblast extracellular matrix and is susceptible to proteolytic processing and release. J. Biol. Chem. 273, 20669-20676 (1998)

17. J.C. Jennings, S. Mohan, T.A. Linkhart, R. Widstrom, D.J. Baylink, Comparison of the biological actions of TGF beta-1 and TGF beta-2: differential activity in endothelial cells. J. Cell. Physiol. 137, 167-172 (1988)

18. J.S. Jeruss, C.D. Sturgis, A.W. Rademaker, T.K. Woodruff, Downregulation of activin, activin receptors, and Smads in high-grade breast cancer. Cancer Res. 63, 3783-3790 (2003)

19. R.L. Jirtle, J.D. Haag, E.A. Ariazi, M.N. Gould, Increased mannose 6-phosphate/insulin-like growth factor II receptor and transforming growth factor beta 1 levels during monoterpene-induced regression of mammary tumors. Cancer Res. 53, 3849-3852 (1993)

20. V.G. Kaklamani, L. Baddi, J. Liu, D. Rosman, S. Phukan, C. Bradley, C. Hegarty, B. McDaniel, A. Rademaker, C. Oddoux, H. Ostrer, L.S. Michel, H. Huang, Y. Chen, H. Ahsan, K. Offit, B. Pasche, Combined genetic assessment of transforming growth factor-beta signaling pathway variants may predict breast cancer risk. Cancer Res. 65, 3454-3461 (2005)

21. T. Kanzaki, A. Olofsson, A. Moren, C. Wernstedt, U. Hellman, K. Miyazono, L. Claesson-Welsh, C.H. Heldin, TGF-beta 1 binding protein: a component of the large latent complex of TGF-beta 1 with multiple repeat sequences. Cell 61, 1051-1061 (1990)

22. B.G. Kim, C. Li, W. Qiao, M. Mamura, B. Kasprzak, M. Anver, L. Wolfraim, S. Hong, E. Mushinski, M. Potter, S.J. Kim, X.Y. Fu, C. Deng, J.J. Letterio, Smad4 signalling in T cells is required for suppression of gastrointestinal cancer. Nature 441, 1015-1019 (2006)

23. E.S. Kim, M.S. Kim, A. Moon, Transforming growth factor (TGF)-beta in conjunction with $\mathrm{H}$-ras activation promotes malignant progression of MCF10A breast epithelial cells. Cytokine 29, 84-91 (2005)

24. D.M. Kingsley, The TGF-beta superfamily: new members, new receptors, and new genetic tests of function in different organisms. Genes Dev. 8, 133-146 (1994)

25. K. Koli, J. Saharinen, M. Hyytiainen, C. Penttinen, J. Keski-Oja, Latency, activation, and binding proteins of TGF-beta. Microsc. Res. Tech. 52, 354-362 (2001) 
26. K. Koli, J. Saharinen, M. Karkkainen, J. Keski-Oja, Novel nonTGF-beta-binding splice variant of LTBP-4 in human cells and tissues provides means to decrease TGF-beta deposition. J. Cell Sci. 114, 2869-2878 (2001)

27. K. Koli, F. Wempe, A. Sterner-Kock, A. Kantola, M. Komor, W. K. Hofmann, M. H. von and J. Keski-Oja, Disruption of LTBP-4 function reduces TGF-beta activation and enhances BMP-4 signaling in the lung. J. Cell Biol. 167, 123-133 (2004)

28. C. Koski, J. Saharinen, J. Keski-Oja, Independent promoters regulate the expression of two amino terminally distinct forms of latent transforming growth factor-beta binding protein-1 (LTBP-1) in a cell type-specific manner. J. Biol. Chem. 274, 32619-32630 (1999)

29. H.M. Kuerer, C.T. Albarracin, W.T. Yang, R.D. Cardiff, A.M. Brewster, W.F. Symmans, N.M. Hylton, L.P. Middleton, S. Krishnamurthy, G.H. Perkins, G. Babiera, M.E. Edgerton, B.J. Czerniecki, B.K. Arun, G.N. Hortobagyi, Ductal carcinoma in situ: state of the science and roadmap to advance the field. J. Clin. Oncol. 27, 279-288 (2009)

30. Q. Li, L. Wu, D.K. Oelschlager, M. Wan, C.R. Stockard, W.E. Grizzle, N. Wang, H. Chen, Y. Sun, X. Cao, Smad4 inhibits tumor growth by inducing apoptosis in estrogen receptor-alpha-positive breast cancer cells. J. Biol. Chem. 280, 27022-27028 (2005)

31. X. Liu, J. Yue, R.S. Frey, Q. Zhu, K.M. Mulder, Transforming growth factor beta signaling through Smad1 in human breast cancer cells. Cancer Res. 58, 4752-4757 (1998)

32. K.J. Livak, T.D. Schmittgen, Analysis of relative gene expression data using real-time quantitative PCR and the 2(-Delta Delta C(T)) Method. Methods 25, 402-408 (2001)

33. X.J. Ma, R. Salunga, J.T. Tuggle, J. Gaudet, E. Enright, P. McQuary, T. Payette, M. Pistone, K. Stecker, B.M. Zhang, Y.X. Zhou, H. Varnholt, B. Smith, M. Gadd, E. Chatfield, J. Kessler, T. M. Baer, M.G. Erlander, D.C. Sgroi, Gene expression profiles of human breast cancer progression. Proc. Natl Acad. Sci. U.S.A. 100, 5974-5979 (2003)

34. S. Mauel, B. Kruse, B. Etschmann, A.G. von der Schulenburg, M. Schaerig, K. Stovesand, B. Wilcken, A. Sterner-Kock, Latent transforming growth factor binding protein 4 (LTBP-4) is downregulated in human mammary adenocarcinomas in vitro and in vivo. APMIS 115, 687-700 (2007)

35. R. McMahon, M. Murphy, M. Clarkson, M. Taal, H.S. Mackenzie, C. Godson, F. Martin, H.R. Brady, IHG-2, a mesangial cell gene induced by high glucose, is human gremlin. Regulation by extracellular glucose concentration, cyclic mechanical strain, and transforming growth factor-beta1. J. Biol. Chem. 275, 9901-9904 (2000)

36. K. Miyazono, A. Olofsson, P. Colosetti, C.H. Heldin, A role of the latent TGF-beta 1-binding protein in the assembly and secretion of TGF-beta 1. EMBO J. 10, 1091-1101 (1991)

37. K. Miyazono, J. Thyberg, C.H. Heldin, Retention of the transforming growth factor-beta 1 precursor in the Golgi complex in a latent endoglycosidase H-sensitive form. J. Biol. Chem. 267, 5668-5675 (1992)

38. T. Mizoi, H. Ohtani, K. Miyazono, M. Miyazawa, S. Matsuno, H. Nagura, Immunoelectron microscopic localization of transforming growth factor beta 1 and latent transforming growth factor beta 1 binding protein in human gastrointestinal carcinomas: qualitative difference between cancer cells and stromal cells. Cancer Res. 53, 183-190 (1993)

39. A. Moren, A. Olofsson, G. Stenman, P. Sahlin, T. Kanzaki, L. Claesson-Welsh, D.P. Ten, K. Miyazono, C.H. Heldin, Identification and characterization of LTBP-2, a novel latent transforming growth factor-beta-binding protein. J. Biol. Chem. 269, 3246932478 (1994)

40. H. Namkoong, S.M. Shin, H.K. Kim, S.A. Ha, G.W. Cho, S.Y. Hur, T.E. Kim, J.W. Kim, The bone morphogenetic protein antagonist gremlin 1 is overexpressed in human cancers and interacts with YWHAH protein. BMC Cancer 6, 74 (2006)

41. T. Nishidate, T. Katagiri, M.L. Lin, Y. Mano, Y. Miki, F. Kasumi, M. Yoshimoto, T. Tsunoda, K. Hirata, Y. Nakamura, Genome-wide gene-expression profiles of breast-cancer cells purified with laser microbeam microdissection: identification of genes associated with progression and metastasis. Int. J. Oncol. 25, 797-819 (2004)

42. R. Oklu, R. Hesketh, The latent transforming growth factor beta binding protein (LTBP) family. Biochem. J. 352(Pt 3), 601-610 (2000)

43. C. Penttinen, J. Saharinen, K. Weikkolainen, M. Hyytiainen, J. Keski-Oja, Secretion of human latent TGF-beta-binding protein-3 (LTBP-3) is dependent on co-expression of TGF-beta. J. Cell Sci. 115, 3457-3468 (2002)

44. B. Romeis, Mikroskopische Technik (Urban \& Fischer, Mchn, 2001)

45. S. Roth-Eichhorn, B. Heitmann, P. Flemming, S. Kubicka, C. Trautwein, Evidence for the decreased expression of the latent TGF-beta binding protein and its splice form in human liver tumours. Scand. J. Gastroenterol. 36, 1204-1210 (2001)

46. G.H. Sakorafas, The origins of radical mastectomy. AORN J. 88, 605-608 (2008)

47. B. Schmierer, C.S. Hill, Kinetic analysis of Smad nucleocytoplasmic shuttling reveals a mechanism for transforming growth factor beta-dependent nuclear accumulation of Smads. Mol. Cell. Biol. 25, 9845-9858 (2005)

48. C.S. Schuetz, M. Bonin, S.E. Clare, K. Nieselt, K. Sotlar, M. Walter, T. Fehm, E. Solomayer, O. Riess, D. Wallwiener, R. Kurek, H.J. Neubauer, Progression-specific genes identified by expression profiling of matched ductal carcinomas in situ and invasive breast tumors, combining laser capture microdissection and oligonucleotide microarray analysis. Cancer Res. 66, 5278$5286(2006)$

49. C. Schulze-Garg, J. Lohler, A. Gocht, W. Deppert, A transgenic mouse model for the ductal carcinoma in situ (DCIS) of the mammary gland. Oncogene 19, 1028-1037 (2000)

50. S. Sinha, C. Nevett, C.A. Shuttleworth, C.M. Kielty, Cellular and extracellular biology of the latent transforming growth factor-beta binding proteins. Matrix Biol. 17, 529-545 (1998)

51. A. Sterner-Kock, I.S. Thorey, K. Koli, F. Wempe, J. Otte, T. Bangsow, K. Kuhlmeier, T. Kirchner, S. Jin, J. Keski-Oja, H. von Melchner, Disruption of the gene encoding the latent transforming growth factor-beta binding protein 4 (LTBP-4) causes abnormal lung development, cardiomyopathy, and colorectal cancer. Genes Dev. 16, 2264-2273 (2002)

52. M.A. Stull, A.M. Rowzee, A.V. Loladze, T.L. Wood, Growth factor regulation of cell cycle progression in mammary epithelial cells. J. Mammary Gland Biol. Neoplasia 9, 15-26 (2004)

53. J. Taipale, K. Miyazono, C.H. Heldin, J. Keski-Oja, Latent transforming growth factor-beta 1 associates to fibroblast extracellular matrix via latent TGF-beta binding protein. J. Cell Biol. 124, 171-181 (1994)

54. J. Taipale, J. Saharinen, K. Hedman, J. Keski-Oja, Latent transforming growth factor-beta 1 and its binding protein are components of extracellular matrix microfibrils. J. Histochem. Cytochem. 44, 875-889 (1996)

55. S.W. Tobin, M.K. Brown, K. Douville, D.C. Payne, A. Eastman, B.A. Arrick, Inhibition of transforming growth factor beta signaling in MCF-7 cells results in resistance to tumor necrosis factor alpha: a role for Bcl-2. Cell Growth Differ. 12, 109-117 (2001)

56. N. Todorovic-Rakovic, TGF-beta 1 could be a missing link in the interplay between ER and HER-2 in breast cancer. Med. Hypotheses 65, 546-551 (2005)

57. T. Tsuji, F. Okada, K. Yamaguchi, T. Nakamura, Molecular cloning of the large subunit of transforming growth factor type beta masking protein and expression of the mRNA in various rat tissues. Proc. Natl Acad. Sci. U.S.A. 87, 8835-8839 (1990) 
58. Y. Wang, W. Zhu, D.E. Levy, Nuclear and cytoplasmic mRNA quantification by SYBR green based real-time RT-PCR. Methods 39, 356-362 (2006)

59. B.J. Warner, S.W. Blain, J. Seoane, J. Massague, Myc downregulation by transforming growth factor beta required for activation of the p15(Ink4b) G(1) arrest pathway. Mol. Cell. Biol. 19, 5913$5922(1999)$

60. L. Ye, S.M. Bokobza, W.G. Jiang, Bone morphogenetic proteins in development and progression of breast cancer and therapeutic potential (review). Int. J. Mol. Med. 24, 591-597 (2009)
61. W. Yin, E. Smiley, J. Germiller, R.P. Mecham, J.B. Florer, R.J. Wenstrup, J. Bonadio, Isolation of a novel latent transforming growth factor-beta binding protein gene (LTBP-3). J. Biol. Chem. 270, 10147-10160 (1995)

62. K. Yoshinaga, H. Obata, V. Jurukovski, R. Mazzieri, Y. Chen, L. Zilberberg, D. Huso, J. Melamed, P. Prijatelj, V. Todorovic, B. Dabovic, D.B. Rifkin, Perturbation of transforming growth factor (TGF)-beta1 association with latent TGF-beta binding protein yields inflammation and tumors. Proc. Natl Acad. Sci. U.S.A. 105, 18758-18763 (2008) 